\title{
MAKING AND UNMAKING BODIES: EMBODYING KNOWLEDGE AND PLACE IN ENVIRONMENTAL HISTORY
}

ALESSANDRO ANTONELLO

University of Melbourne

RUTH A. MORGAN

Monash University

\section{An earthly body under siege}

'The Great Barrier Reef is in grave danger', despaired Sir David Attenborough when he returned after some 60 years to the reef in 2015. The Earth's largest living structure and home to the world's largest coral reef system, the Great Barrier Reef is experiencing significant challenges that threaten its existence as we know it.

We open this special issue 'Bodies of Knowledge' by invoking the recent history and deep past of the reef-a vast earthly body under siege. What Attenborough's exploration of the reef highlighted was the gulf between knowing about the reef's challenges and acting upon that knowledge. He wondered, 'do we really care so little about the earth upon which we live that we don't wish to protect one of its greatest wonders from the consequences of our behaviours?' In bridging this gap, the historian Iain McCalman suggests that environmental history has a valuable affective role to play by making the past meaningful to the present and the future. A meaningful or 'passionate history', as McCalman shows in his own biography of the reef, is one that populates or embodies the past. ${ }^{2}$ We take to the reef ourselves to illuminate the historiographical and conceptual issues that animate the contributions to this special issue. What we know about environments, and how we know them, affects the ways we relate to and engage with them, and how we embody them, physically and culturally, over time.

In the late southern hemisphere summer of 2016, a bleaching event affected nearly a third of the corals of the Great Barrier Reef, concentrated in its far northern reaches. Bleaching corals are corals starving to death: corals bleach when they expel the algae

1 David Attenborough's Great Barrier Reef, Atlantic Productions (2015), aired on ABC TV on 10, 17 and 24 April 2016.

2 Iain McCalman, The Reef: A Passionate History (Melbourne: Viking, 2013). 
that live inside them and on which they rely for energy to grow and reproduce. The following summer of 2016-17, after a winter of above-average sea surface temperatures, the stressed and vulnerable corals of the central reef succumbed to another episode of mass bleaching. ${ }^{3}$ This second bleaching was driven by ocean warming - a result of climate change and a significant El Niño event. The Great Barrier Reef, running along the coast of the Australian state of Queensland, was not the only reef to so suffer the accumulated strain of climate change-induced heat. Corals living on reefs in the Seychelles, New Caledonia and the United States, among others, also bleached. In fact, scientists and other authorities have reported that such coral bleachings are part of a continuous trend that has been affecting tropical regions since $2014 .^{4}$

Other events have also challenged the reef in recent times. In March 2017, the category 4 Tropical Cyclone Debbie stormed through the southern Pacific onto the north Queensland coast, with devastating winds blasting islands and low-lying areas in its wake. Little was left unscathed in what was the worst cyclone to hit the region since 2011. The reef too endured unprecedented damage, as Debbie's turbulence scattered corals and blanketed the archipelago with heavy sediment. ${ }^{5}$ Although tropical cyclones are familiar foes for the reef, Debbie arrived after a second consecutive year of mass coral bleaching in its northern reaches, which had already reduced the capacity of the reef in these areas to recover. A weakened reef is also vulnerable to the predations of the crown-of-thorns starfish (Acanthaster planci), which is one of two leading causes of the decline of the reef's corals since the 1970s. ${ }^{6}$ Ravenous starfish, combined with the greater likelihood of bleaching and extreme weather events like Debbie, suggests that the Great Barrier Reef faces an especially difficult future.

What made these bleaching events and climate extremes historical rather than merely natural occurrences was that they were so profoundly entangled in modern industrialised human life and its accompanying ways of knowing. Not only have bleachings occurred because of accumulated bio-geophysical effects, but they are also understood through accumulated knowledge. Much, of course, is known

3 Michelle Innis, 'Climate-Related Death of Coral Around World Alarms Scientists', New York Times, 9 April 2016, www.nytimes.com/2016/04/10/world/asia/climate-related-death-of-coral-around-world-alarms-scientists.html, accessed 8 September 2017.

4 Great Barrier Reef Marine Park Authority (GBRMPA), Final Report: 2016 Coral Bleaching Event on the Great Barrier Reef (Townsville: GBRMPA, June 2017), iv.

5 Kathy McLeish, 'Great Barrier Reef photos show "striking” damage to coral after Cyclone Debbie', $A B C$ News, 13 July 2017, www.abc.net.au/news/2017-07-13/comparison-photos-striking-damage-great-barrier-reef-cycloneqld/8702192, accessed 8 September 2017.

6 Dani Cooper, 'Crown-of-thorns starfish DNA reveals coral killer's weakness', ABC News, April 6, 2017, www.abc.net.au/news/science/2017-04-06/crown-of-thorns-starfish-dna-reveals-coral-killers-weakness/8415058, accessed 8 September 2017. 
about the reef in different scientific and management disciplines, yet there is still more that could be known. In his 'passionate' history of the reef, McCalman observes, ' $[t]$ he Great Barrier Reef is so extensive that no human mind can take it in'.

Whatever is known or can be known about the reef is the product of entangled natural and human histories. Each article in this special issue also interrogates what is known about environments and how that knowledge has emerged from specific human and natural histories. Such is the scale and significance of the reef that the effort to know its nature and extent is the labour of generations. For someIndigenous Australians - those generations are many, while for others-particularly European settlers-those generations are comparatively few. Consequently, knowledge of the reef has developed in different ways, shaped by different cultural traditions and environmental conditions.

Although scenarios for a warmer future suggest the Great Barrier Reef is likely to undergo significant and accelerated change, local Indigenous knowledge reveals the reef's long history of change and becoming. Gungganyji and Indindji people describe a time when the coastline was 'once where the barrier reef now stands ... but the sea then rose and the shore retreated to its present position'. According to the Gungganyji, this inundation was a divine punishment for trespassing against food customs, which drowned the perpetrator's family and dispersed the local peoples 'to their present-day territories' ${ }^{8}$ Today, the Great Barrier Reef Marine Park Authority co-manages the area off the Queensland coast, drawing on both Western science and the traditional ecological knowledge of Indigenous peoples that has been forged over thousands of years.

For those who lack such a cultural connection to deep time, the warmer future that anthropogenic climate change is fermenting is nearly impossible to comprehend. But comprehending and communicating this future is not simply a task for climate scientists. In his recent study The Great Derangement, the novelist and critic Amitav Ghosh urges the arts to radically engage with the unfolding planetary crisis. Without this commitment, Ghosh predicts that our descendants will look back and 'conclude that ours was a time when most forms of art and literature were drawn into the modes of concealment that prevented people from recognizing the realities of their plight'. ' Living in a changing climate demands we harness all bodies of knowledge, which can provide us the means with which to come to terms with the climate crisis not only as a wicked problem of governance and markets, but also as a 'crisis of culture, and thus of the imagination'. ${ }^{10}$

7 McCalman, The Reef, 3.

8 Patrick D. Nunn and Nicholas J. Reid, 'Aboriginal Memories of Inundation of the Australian Coast Dating from More than 7000 Years Ago', Australian Geographer 47, no. 1 (2016): 23.

9 Amitav Ghosh, The Great Derangement: Climate Change and the Unthinkable (Chicago: University of Chicago Press, 2016), 11.

10 Ghosh, The Great Derangement, 9. 
McCalman's history of the Great Barrier Reef makes a strong case for embracing such a holistic conceptualisation of our world. He demonstrates clearly the ways in which the knowledge and life of the reef-both for Indigenous people and settlers alike-were embodied in oral lore, cultural practice and written word. The reef, for example, can be found in the English navigator Matthew Flinders' A Voyage to Terra Australis (1814): for McCalman, the reef's 'foundation document'. ${ }^{11}$ Likewise, the notion of the 'reef-as-beautiful' has its origins in the works of the English geologist Joseph Jukes, who studied it during the 1843-45 voyage of HMS Fly. ${ }^{12}$ But McCalman carefully shows that knowledge of the reef was not only embodied in literature, but also in people's relationships with each other and with the reef. Take for instance, the naturalist Ted Banfield. Although he committed his thoughts to paper in works such as Confessions of a Beachcomber (1908), it was through his encounters with local Aboriginal peoples that he developed his 'distinctive beachcomber philosophy'. According to McCalman, Banfield thought 'that individuals must develop "a sense of fellowship with animated and inanimate things" within their country'. ${ }^{13}$ Such experiences suggest that knowledge of the reef has formed cumulatively, resulting from the work of many people, and becomes embodied in myriad ways.

Institutions are also embodiments of reef knowledge and shape particular narratives of knowledge. The historian Rohan Lloyd suggests that one of the main repositories of knowledge and institutions for action, the Great Barrier Reef Marine Park Authority (established in 1975), views the reef through a 'threat' paradigm. Indeed, Lloyd's insight might be extended to suggest that all modern reef institutions see it through a threat lens. ${ }^{14}$ For example, the 'Save the Reef' campaign of environmentalists and other concerned parties (1967-76) protested against concerted efforts to explore the reef's potential oil and mineral resources for exploitation. ${ }^{15}$ Threat is similarly the principal lens through which the United Nations Educational, Scientific and Cultural Organization (UNESCO) and its World Heritage Committee view the reef, which was inscribed on the World Heritage List in 1981.

It was also threat through which Queensland's thriving tourism industry regarded the recent bleaching events on the reef. The industry's viability depends on a healthy reef-both physically and in terms of its reputation. When the UNESCO World Heritage Committee declined to register the reef as 'in danger', despite two

11 McCalman, The Reef, 58.

12 McCalman, The Reef, 103-4.

13 McCalman, The Reef, 210.

14 Rohan Lloyd, 'Through the Reef: Settler Politics, Science, and the Great Barrier Reef', in Visions of Australia: Environments in History (RCC Perspectives, 2: Transformations in Environment and Society), ed. Christof Mauch, Ruth Morgan and Emily O'Gorman (Munich: Rachel Carson Center, 2017), 89, doi.org/10.5282/rcc/7912.

15 McCalman, The Reef; James Bowen and Margarita Bowen, The Great Barrier Reef: History, Science, Heritage (Cambridge: Cambridge University Press, 2002); Rohan Lloyd, 'Fathoming the Reef: A History of European Perspectives on the Great Barrier Reef from Cook to GBRMPA' (PhD diss., James Cook University, 2016); Judith Wright, The Coral Battleground (Melbourne: Nelson, 1977). 
sequential bleaching events and a national government that prefers coal extraction to environmental protection, local tour operators were greatly relieved. ${ }^{16}$ They had feared that a negative assessment of the reef's health would likely deter prospective visitors with its moribund connotations of an ailing ecosystem. In each of these cases of institutional bodies and their knowledge, what is known in a scientific sense meshes with what is known from cultural and political perspectives-assessments of threat and risk enrolling scientific data and knowledge into contestable fields of regulatory and institutional action.

Yet actors within the central institutions of the Australian polity-parliament and government-have forsaken scientific and cultural knowledge for obfuscation and cultivated doubt. ${ }^{17}$ Although the 2016-17 bleachings produced dead coral in the ocean and prompted alarm among reef scientists, Australian politicians in Canberra and Brisbane enrolled its unfolding crisis into their own attempts to form and frame what was 'known', in terms of what was significant and worthwhile considering. Coal, corporations and workers were seen as more significant than the complex natural assemblage of the reef and its wider cultural and ecological import. ${ }^{18}$ The government-approved, though still uncertain, Carmichael coal mine in remote central Queensland will bring significant impacts to the reef if it proceeds; not simply local impacts, but also continuing the pumping of carbon into the atmosphere and further guaranteeing climate change. The disingenuous, deliberately obfuscatory rhetoric and actions of politicians aiding construction of the coal mine contribute to the erosion of trust between the nation's political institutions and its citizensthe very bodies that constitute modern democracies and compose potentially more sustainable social-ecological systems. ${ }^{19}$

Reflecting on the human and natural histories of the Great Barrier Reef reveals just some of the ways that this coral archipelago has been understood in deep and more recent times. These histories of the reef offer insight into the connections between

16 Colin Packham and Benjamin Cooper, 'UNESCO leaves Great Barrier Reef off “in danger” list', Reuters, 5 July 2017, www.reuters.com/article/us-australia-environment-reef-idUSKBN19R07S, accessed 8 September 2017.

17 On the question of 'cultivated doubt', we gesture towards the work of Robert Proctor. See, for example, Robert N. Proctor and Londa Schiebinger, eds, Agnotology: The Making and Unmaking of Ignorance (Stanford, CA: Stanford University Press, 2008).

18 Just how many people will be employed in the Carmichael coal mine remains unclear. Federal and state governments, as well as the Adani company, claim that the project will generate '10,000 direct and indirect jobs', while other estimates - produced by the Queensland Land Court and Adani's own experts—suggest that fewer than 1,500 jobs will be created. For insight into this conflict, see Joshua Robertson, 'Adani gives "green light" to \$16bn Carmichael coal mine', Guardian, 6 June 2017, www.theguardian.com/environment/2017/jun/06/ adani-gives-green-light-to-16bn-carmichael-coal-mine; and Felicity Caldwell, 'Adani Carmichael mine: Drilling into the numbers for Queensland', Sydney Morning Herald, 6 December 2016, www.smh.com.au/business/ mining-and-resources/adani-carmichael-mine-drilling-into-the-numbers-for-queensland-20161206-gt4t8n.html, accessed 8 September 2017.

19 'Pauline Hanson visits healthy reef to dispute effects of climate change', ABC News, 25 November 2016, www.abc.net.au/news/2016-11-25/pauline-hanson-visits-the-great-barrier-reef-climate-change/8059142, accessed 8 September 2017. 
material and cultural bodies, and to the influence of complex geological, ecological, economic and cultural systems and processes on these relationships. The articles in this special issue similarly attempt to trace the diverse ways in which humans have interpreted material bodies and developed knowledge about them. Opening with the embattled corals of the reef, therefore, sets the scene for generating more embodied and affective environmental histories through our focus on the making of environmental knowledge in Asia, Australia and Antarctica from the nineteenth century.

\section{Bodies in mind, bodies in place, bodies in relation}

As our brief survey of the Great Barrier Reef suggests, the field of environmental history aspires to investigate whole environments as complex assemblages of nature, and the myriad ways in which humans - both individually and collectively—engage with and affect them over time. In pursuit of these aims, the field continues to grow and form a complex body of scholarship that responds to both local and global environmental challenges. The six articles of this special issue 'Bodies of Knowledge' speak to this historiographical literature, while articulating alternative pathways for environmental historians. At the centre of our frame of investigation are morethan-human bodies — small and large, biological and geological — and the ways they have been known and understood. In more and less explicit ways, each contributor is concerned with understanding how a particular more-than-human body is known - that is, with the various political, cultural and historical contestations involved in both the acts and processes of knowing, and the dissemination of that knowledge. In their own ways, these contributions respond to recent trends in historical scholarship, particularly those that focus on the formation, function and impact of human and more-than-human networks and agencies. Drawing on a wide range of scholarly literature, the contributors demonstrate that the human interpretations of more-than-human natures remain fundamentally important and urgent topics of investigation for environmental historians.

If bodies of knowledge continue to warrant careful historical analysis, as we contend, it is useful to reflect on the development of our own body of knowledge. Although environmental historians have attracted criticism for avoiding social and political theory, the field has not escaped the influence of other approaches that seek to make sense of the relations between humans and the more-than-human world. ${ }^{20}$ The work of Donna Haraway, for example, informs a great deal of work in environmental history, the history of science and the wider environmental

20 Paul Warde and Sverker Sörlin, 'The Problem of the Problem of Environmental History: A Re-Reading of the Field', Environmental History 12, no. 1 (2007): 107-30; Kristen Asdal, 'The Problematic Nature of Nature: The Post-Constructivist Challenge to Environmental History', History and Theory 42, no. 4 (2003): 60-74. 
humanities. Consider her significant 1988 article 'Situated Knowledges'. Building upon scholarship in feminist science studies, Haraway was determined to hold up what she described as 'embodied vision'. She argued 'for the view from a body, always a complex, contradictory, structuring, and structured body, versus the view from above, from nowhere, from simplicity. Only the god trick is forbidden'. ${ }^{21}$ She advocated not for the sacrifice of objectivity, but rather a feminist objectivity that values embedded, embodied and relational ways of seeing. In ways that resonate with Haraway's approach, environmental historians have sought not to discard the material (the 'object' of objective gaze), but rather to understand it as seen, understood and shaped through historical, and, therefore, politically and culturally constituted, processes.

Historians, certainly those working in the history of science and to a lesser extent environmental history, have demonstrated the ways in which scientific knowledge is the product of specific times, actors and places. ${ }^{22} \mathrm{~A}$ generation ago, it was commonplace for environmental historians to unquestionably rely on the science and metaphors of ecology, for instance. ${ }^{23}$ Since then, however, environmental historians have undertaken more critical approaches to understanding the production of scientific knowledge of the environment. In a 2014 forum on climate change in the journal Environmental History, for example, the editors Mark Carey and Philip Garone stressed the need to historicise the ways that humans narrate and quantify climate. ${ }^{24}$ They also warned environmental historians that 'we cannot accept the natural sciences at face value, that we have to remain critical of the social contexts in which science is produced in both the past and present'. ${ }^{25}$ Pey-Yi Chu's recent work on permafrost in Russia similarly problematises any sense of predetermined scientific and environmental categories. In doing so, she illuminates the ways in which scientific work interacts with politics and culture 'to create a quantifiable and geographically defined object', what she calls an 'environmental object'. ${ }^{26}$ In these

\footnotetext{
21 Donna Haraway, 'Situated Knowledges: The Science Question in Feminism and the Privilege of Partialperspective', Feminist Studies 14, no. 3 (1988): 589.

22 David N. Livingstone, Putting Science in Its Place: Geographies of Scientific Knowledge (Chicago: University of Chicago Press, 2003); Steven Shapin, 'Placing the View from Nowhere: Historical and Sociological Problems in the Location of Science', Transactions of the Institute of British Geographers 23, no. 1 (1998): 5-12.

23 Donald Worster, 'The Ecology of Order and Chaos', Environmental History Review 14, no. 1/2 (1990): 1-18; Richard White, 'Environmental History, Ecology, and Meaning', Journal of American History 76, no. 4 (1990): 1111-16; Douglas R. Weiner, 'A Death-Defying Attempt to Articulate a Coherent Definition of Environmental History', Environmental History 10, no. 3 (2005): 404-20.

24 Mark Carey and Philip Garone, 'Forum Introduction: Climate Change and Environmental History', Environmental History 19, no. 2 (2014): 287-8, doi.org/10.1093/envhis/emu004.

25 Carey and Garone, 'Climate Change and Environmental History', 290.

26 Pey-Yi Chu, 'Mapping Permafrost Country: Creating an Environmental Object in the Soviet Union, 1920s-1940s', Environmental History 20, no. 3 (2015): 397, doi.org/10.1093/envhis/emv050. Resonant with Chu's work is Alessandro Antonello, 'Engaging and Narrating the Antarctic Ice Sheet: The History of an Earthly Body', Environmental History 22, no. 1 (2017): 77-100, doi.org/10.1093/envhis/emw070.
} 
recent works, among others, historical scholarship is revealing the ways in which power dynamics shape bodies of environmental knowledge and their articulations of the more-than-human world.

As environmental historians, we should also be especially attuned to the role of place in the production of environmental knowledge. Where bodies of knowledge are formed (and how) influences the very nature of that particular knowledge. ${ }^{27}$ Some environmental knowledge might be gleaned by researchers in the field or the laboratory, while others are forged through manual labour. ${ }^{28}$ Wherever such bodies of knowledge develop, those are specifically local sites-positions in which humans experience and comprehend the more-than-human world, whether directly or in mediated ways. It is in these sites that different human experiences shape particular knowledge, which embodies their own understandings of the dynamics of social and natural worlds. A place, therefore, both produces and is produced by bodies of knowledge. The act of being situated in a place, as Heather Goodall and Allison Cadzow argue, 'makes [a] place meaningful, not the material of the place itself'. ${ }^{29}$ This perspective offers a critical opportunity for environmental historians to make places meaningful - to narrate stories that connect people to a locale and to facilitate their embodiment in familiar and unfamiliar places. Through environmental narratives, we can make visible planetary change in particular places such as the bleached stretches of the Great Barrier Reef.

Despite the importance of singular locales to forming some bodies of knowledge, others are created across and between multiple sites. These trans-local bodies of knowledge identify connections, produce networks to connect sites or 'nodes', constitute scale and space, and both mobilise and interpret processes of human and more-than-human exchange between them. The transatlantic processes that Alfred Crosby mapped in The Columbian Exchange (1972) and Ecological Imperialism (1986), for example, were the product of western European knowledge that drove commerce, conquest and conversion. The resulting cultural and biological exchanges fundamentally transformed peoples and environments in both the Old World and the New, while shaping European and non-European bodies of knowledge (such as, for example, economic botany, medicine and lore) about these trans-local impacts.

27 Tim Ingold's work is especially instructive for understanding how human beings relate to their environments and the implications of these relations for knowledge or 'perception'. See, for example, Tim Ingold, 'Culture and the Perception of the Environment', in Bush Base, Forest Farm: Culture, Environment and Development, ed. Elisabeth Croll and David Parkin (London: Routledge, 1992), 39-56; Tim Ingold, The Perception of the Environment: Essays on Livelihood, Dwelling and Skill (London: Routledge, 2000).

28 See, for example, Marybeth Long Martello and Sheila Jasanoff, 'Introduction: Globalization and Environmental Governance', in Earthly Politics: Local and Global in Environmental Governance, ed. Sheila Jasanoff and Marybeth Long Martello (Cambridge, MA: MIT Press, 2004), 19; Heather Goodall and Allison Cadzow, Rivers and Resilience: Aboriginal People on Sydney's Georges River (Sydney: UNSW Press, 2009), 16; Richard White, “Are You an Environmentalist or Do You Work for a Living?": Work and Nature', in Uncommon Ground: Rethinking the Human Place in Nature, ed. William Cronon (New York: W. W. Norton, 1996), 171-85.

29 Goodall and Cadzow, Rivers and Resilience, 16. 
Furthermore, this traffic and its associated knowledge later came to configure the shape of a triangular Atlantic world stretching from Europe to the Americas and West Africa. ${ }^{30}$

Studying such trans-local exchanges reveals not only spatial and temporal patterns of human and more-than-human mobility, but also the movement (or inertia) of bodies of knowledge. The practices of Western science and commerce largely 'stripped' Indigenous narratives of meaning from the bodies that imperial actors extracted from the periphery in the process of building their own bodies of knowledge. ${ }^{31}$ But this process of elision could be illusory. As Judith Carney showed in Black Rice (2001), the transatlantic slave trade transported not only human bodies, but their accompanying bodies of knowledge. Rice cultivation in South Carolina was the product of both the physical labour of West African slaves and their West African rice cultures, such that an 'entire agricultural system' was transplanted in the Americas. ${ }^{32}$

As the example of transatlantic slavery suggests, what and who moves through an 'eco-cultural network' reflects what the geographer Doreen Massey calls the 'powergeometry' of such relationships. ${ }^{33}$ Although Massey is concerned with human bodies, this geometry accounts for the mechanics of trans-local exchanges and mediates the agency of the human and more-than-human bodies in those networks. She writes:

different social groups and different individuals are placed in very distinct ways in relation to these flows and interconnections. This point concerns not merely the issue of who moves and who doesn't, although that is an important element of it; it is also about power in relation to the flows and the movement $\ldots$ at the end of all the spectra are those who are both doing the moving and the communicating and who are in some way in a position of control in relation to it. ${ }^{34}$

30 Alfred W. Crosby, The Columbian Exchange: Biological and Cultural Consequences of 1492 (Westport, CT: Greenwood, 1972) and Ecological Imperialism: The Biological Expansion of Europe, 900-1900, 2nd ed. (Cambridge: Cambridge University Press, 2004). In addition to Crosby, see, for example, Lucile Brockway, Science and colonial expansion: The role of the British Royal Botanic Gardens (New York: Academic Press, 1979); Richard Drayton, Nature's Government: Science, Imperial Britain, and the 'Improvement' of the World (New Haven, CT: Yale University Press, 2000); J. R. McNeill, Mosquito Empires: Ecology and War in the Greater Caribbean, 1620-1914 (New York: Cambridge University Press, 2010). For recent work on other oceanic 'worlds', see Gregory T. Cushman, Guano and the Opening of the Pacific World: A Global Ecological History (New York: Cambridge University Press, 2013); Vinita Damodaran, Anna Winterbottom and Alan Lester, eds, The East India Company and the Natural World (Basingstoke: Palgrave Macmillan, 2015).

31 Londa Schiebinger, 'Prospecting for Drugs: European Naturalists in the West Indies', in Colonial Botany: Science, Commerce, and Politics in the Early Modern World, ed. Londa Schiebinger and Claudia Swan (Philadelphia, PA: University of Pennsylvania Press, 2004), 128.

32 Judith Carney, Black Rice: The African Origins of Rice Cultivation in the Americas (Cambridge, MA: Harvard University Press, 2001).

33 On 'eco-cultural networks', see James Beattie, Edward Melillo and Emily O'Gorman, eds, Eco-Cultural Networks and the British Empire: New Views on Environmental History (London: Bloomsbury, 2015).

34 Doreen Massey, 'Power-geometry and a progressive sense of place', in Mapping the Futures: Local Cultures, Global Change, ed. Jon Bird, Barry Curtis, Tim Putnam, George Robertson and Lisa Tickner (London and New York: Routledge, 1993), 62. 
Massey's logic extends to understanding which bodies of knowledge are dominant in these networks. How such bodies of knowledge form, and consequently interpret and order human and more-than-human worlds, is the product of these dynamics.

If we cannot ignore the ways that the more-than-human world shapes human possibilities, then the agency of more-than-human bodies and phenomena in knowledge-making also needs to be considered. Environmental historians have been increasingly sensitive to the ways in which the more-than-human eludes and transgresses human boundaries, whether it is the migratory birds that travel up and down North America, or the weeds that skip property boundaries and frustrate grand settler and agricultural projects. ${ }^{35}$ The question of such more-than-human agency has been a contested one for environmental historians. ${ }^{36} \mathrm{~A}$ way through this dilemma might be found in Elspeth Probyn's recent study of human relationships with the ocean and fish, especially as food. Following Annemarie Mol and her Eating Body team, she argues that we need not search for agency at all costs. Instead, she contends, we could consider 'matter-in-relation'. Doing so acknowledges the ways in which bodies of knowledge mediate more-than-human matter and how it is related to other bodies, both more-than-human and human. ${ }^{37}$ Using the narrative tools of history, environmental historians can illuminate the complex historical relationships between these bodies of matter and knowledge, the production of place and their processes of becoming.

As our discussion suggests, studies of environmental history and histories of science show that the making of knowledge is an inherently networked or relational process between subject and object. Yet none of our articles are explicitly driven by this recent turn to 'networked', or spatial, frameworks of connection, transfer and exchange. Rather than focus on the processes of exchange themselves, the articles in this special issue consider instead bodies of knowledge in states of becoming. Likewise, the contributors are concerned more with how these bodies of knowledge allow humans to speak for the non-human, on what basis and with what effects, than with determining if mosquitoes (or earthquakes) can speak for themselves, as Timothy Mitchell and Giacomo Parrinello have speculated. ${ }^{38}$ Historicising and placing these bodies of knowledge—whether fishing lore or hydrology, restoration

35 These are merely two examples from among much scholarship: Robert M. Wilson, Seeking Refuge: Birds and Landscapes of the Pacific Flyway (Seattle, WA: University of Washington Press, 2010); Mark Fiege, 'The Weedy West: Mobile Nature, Boundaries, and Common Space in the Montana Landscape', Western Historical Quarterly 36, no. 1 (2005): 22-47, doi.org/10.2307/25443584.

36 Timothy Mitchell, Rule of Experts: Egypt, Techno-Politics, Modernity (Berkeley, CA: University of California Press, 2002); Linda Nash, 'The agency of nature or the nature of agency?' Environmental History 10, no. 1 (2005): 67-9; Paul S. Sutter, 'Nature's Agents or Agents of Empire? Entomological Workers and Environmental Change During the Construction of the Panama Canal', Isis 98, no. 4 (2007): 724-54, doi.org/10.1086/529265.

37 Elspeth Probyn, Eating the Ocean (Durham, NC: Duke University Press, 2016), 11.

38 Mitchell, Rule of Experts; Giacomo Parrinello, Fault Lines: Earthquakes and Urbanism in Modern Italy (New York and Oxford: Berghahn, 2015). 
ecology or glaciology—reveals the power relations that underpin their making and their deployment in Southeast Asia, Australia and Antarctica during the nineteenth and twentieth centuries.

\section{Bodies of Knowledge}

Each of the articles in this special issue addresses aspects of knowing the morethan-human world, whether for the purposes of economic exploitation; protection of human and more-than-human communities; anticipation and prediction of environmental change and risk; or for the restoration of particular ecologies. The contributors show that the ways of knowing the world are multiple, ranging from understandings drawn from labour, emotion and Western science, to imagination, bureaucracy and tradition.

We begin at the turn of the twentieth century with a London-born, Scottish-trained engineer grappling with the hydrology of south-east Queensland. The protagonist of Margaret Cook's study had to determine how to best manage the flood-prone Brisbane River and to protect inhabitants residing on its banks. His reading of the river was both local and trans-local, observing local climatic variations that he interpreted through hydrological knowledge gleaned from French and British colonial experience in other settings. As Cook shows, his environmental knowledgemaking defied the conventions of his field, in favour of a more place-based and, ultimately, state-building approach to hydrological measurement and management in a sub-tropical climate.

We then travel north to the American-occupied archipelago of the Philippines and the scientific expedition of the SS Albatross. Sponsored by the Smithsonian Institution in Washington, DC, this three-year expedition reflected the imperial dynamics of metropolitan marine science. As part of the colonial project to accumulate environmental knowledge, Ruel Pagunsan argues, the scientists on board collected not only specimens, but also the traditional bodies of water knowledge of local peoples. In aid of their labour was the SS Albatross itself, a floating laboratory designed especially for oceanographic research, which was a site for knowledgemaking as much as a vessel for conveying knowledge and connecting human and more-than-human bodies across the Pacific in the early twentieth century.

Although our focus on bodies of knowledge may suggest the precedence of Western scientific labour, this special issue considers other forms of knowing. Bodies of knowledge about the more-than-human world can be formed through the act of working the environment, through physical labour, as Goodall's study of the Darling River in New South Wales suggests. Not only do people work on or near the river, as with fishing for example, but they also put the river to work, through irrigation. As Goodall puts it, 'the goals and technologies of that work have shaped what people 
could know about the river, what they noticed and how they understood it', and indeed determine ideas of whether the river is working 'well'. In working the river, people create stories of local knowledge. Goodall takes a broad and encompassing view of knowledge here, clearly showing how knowledge of the river not only materially sustains human communities, but also sustains them with meaning. The people who travel around the river and its region carry that knowledge in them.

From the embodied riverine knowledge of New South Wales, we head south to explore the glaciological knowledge that developed, within an international scientific and geopolitical context, in Victoria and Tasmania after the Second World War. The focus of this scientific knowledge was the Antarctic ice sheet, a geographical feature of such scale and complexity that a generation of Australian glaciologists could constitute and advance their own cryo-imaginary. To show how this knowledge configured an Australian Antarctica, Alessandro Antonello draws together a trio of 'glaciological bodies'-the ice sheet itself, as well as the institutions and glaciologists that explored and researched the ice during the era of internationalising the ice sheet.

The ways in which knowledge is generated and inflected by aspirations for human development and improvement is at the heart of Ruth Morgan's article. 'Dry Continent Dreaming' examines the Australian contribution to the global push for Antarctic iceberg utilisation in the 1970s and 1980s. Though a seemingly overambitious attempt to master some of the wildest nature on earth (and immediately calling to mind the 'high modernism' investigated by James C. Scott), the story of iceberg utilisation, Morgan contends, is one that demonstrates the tenacity of colonial and imperial visions of improvement in the late twentieth century. Furthermore, it suggests the ways in which knowledge, broadly construed, co-constitutes frontiers (Australia and Antarctica) and can spur innovation and bold schemes rather than foreclose them. To understand the persistence of those scientists-many reputable and eminent- to engineer what seemed an overly ambitious scheme, Morgan uses Patrick McCray's concept of 'visioneers', which denotes the thinkers who are hybrid futurists, researchers and promoters of particular schemes. In the case of Western Australia's utilisation of Antarctic icebergs, the visioneers imagined they had found a solution to the hydrological limits of the growing capital city of Perth.

Just as Morgan shows the influence of colonial narratives on schemes for iceberg utilisation, the role of history in shaping ecological restoration practices is at the heart of our final article. Lilian Pearce studies the place of history-not simply the events and developments of the past, but the stories told (and not told) about the past-in ecological restoration in the New South Wales South Coast town of Bermagui. Pearce interrogates the ways certain emotional practices in ecological restoration work, such as loving, labouring, learning and 'letting go', help to generate new histories as much as restore a local environment that bears the scars of settler histories. History here is not simply a range of stories or already-formed 
bodies of knowledge to draw upon for successful ecological restoration. Rather, new histories are generated through the very act of ecological restoration, through the labour and love of volunteers who weed the ground and rehabilitate their local environment. As Pearce shows, ecological restoration finds itself in a delicate balance: it inherits and must address complex settler histories as well as forge new, generative histories. Where dominant historical narratives might constrain rather than enliven restoration work, volunteers demand new narratives to enrich and sustain their practice. Pearce's article articulates the broad sphere of work that counts as 'environmental history' and its interfaces with ecological practice, as well as the broader environmental humanities.

Embodying environmental history reflects a growing scholarship that attends to more-than-human bodies, both static and mobile, and the bodies of knowledge that draw them into the human world. Looking more closely at these inter-related bodies encourages us to repopulate planetary and global histories - that is, to embody these histories with specific matter and biota that reside in and move between particular places. An embodied environmental history is fundamentally a relational history that narrates the material and cultural connections between human and more-thanhuman worlds that foster more meaningful cultural embodiments of place.

\section{Acknowledgements}

The articles in this special issue are drawn from a symposium held on the lands of the Wattmattageal clan of the Darug nation at Macquarie University, Sydney, in February 2016, titled 'Foreign Bodies, Intimate Ecologies: Transformations in Environmental History'. The editors are grateful for the endeavours of their fellow symposium conveners Emily O'Gorman, Christof Mauch and Cameron Muir. The symposium was only possible with the generous support of the Department of Geography and Planning, Macquarie University; the Faculty of Arts, Monash University; the Centre for Environmental History, The Australian National University; the International Water History Association; the Sydney Environment Institute, University of Sydney; and the Rachel Carson Center for Environment and Society, Ludwig-Maximilian University, Munich. The editors also acknowledge the contribution of referees whose feedback strengthened the individual articles and the special issue as a whole. Finally, the editors thank James Beattie and the University of Melbourne for supporting the publication of this special issue. 
This text is taken from International Review of Environmental History, Volume 4, Issue 1, 2018, edited by James Beattie, published 2018 by ANU Press, The Australian National University, Canberra, Australia.

doi.org/10.22459/IREH.04.01.2018.05 